\title{
Assignments Method in Infrastructure Development: Opportunities And Challenges
}

\author{
Ricca Anggraeni ${ }^{1}$, Cipta Indra Lestari Rachman ${ }^{2}$, Indah Mutiara Sari ${ }^{3}$ \\ \{riccaanggraeni@univpancasila.ac.id ${ }^{1}$,cipta.rachman@yahoo.com ${ }^{2}$, mutiaraheart@gmail.com ${ }^{3}$ \} \\ Pancasila University, Indonesia ${ }^{123}$
}

\begin{abstract}
Infrastructure, has become a pride in President Joko Widodo's government. Various policies were decided to support infrastructure development including the method of Public Private Partnership (PPP) as outlined in Presidential Regulation No. 38 of 2015. However, the provisions regarding the selection of an Implementing Business Entity (IBE) of infrastructure that should have been carried out only through 2 (two) methods, namely auction or direct appointment, in practice were broken by the government itself by using other methods, namely assignments, as what happened in the construction of Light Rail Transit infrastructure integrated (LRT) for Jakarta, Bogor, Depok and Bekasi. Of course this becomes a problem that must be clarified, regarding the opportunity to do the assignment method, and what conditions makes the government use the assignment method to select the implementing business entity of infrastructure. Then, what are the potential conflicts of interest in the assignment method? This problem is solved through research based on a normative approach using the secondary data.
\end{abstract}

Keywords: Assignment; Public Private Partnership; Conflict of Interest; Infrastructure

\section{Introduction}

Since 2015 the trend of infrastructure development in Indonesia has increased. This can be seen from the enhancement in budget allocations for infrastructure in the National Budget from 2015 to 2019. Even for 2019, the allocation reaches Rp. 420, 5 trillion, up about 10 trillion from the budget allocation in 2018. The enhancement in the budget sends a message that the Government will continue to improve infrastructure development in Indonesia. If it refers to what was presented by the President of the Republic of Indonesia, Joko Widodo, that the amount of the budget will be used to increase the length of national roads, widening, building railroads, energy infrastructure, such as power plants. In addition, it also facilitates digital infrastructure, and the provision of drinking water.

However, the high enhancement in the budget for infrastructure, is not entirely positive as a result of infrastructure development, which is intended to improve economic growth and the welfare of the Indonesian people. The budget deficit is indicated as a negative impact of high infrastructure financing in Indonesia, due to the priority of budget spending for infrastructure projects with low financial benefits. It can be seen from the data that the growing infrastructure budget is not accompanied by an increase in GDP's growth, at least in 2017.

Realizing this, various efforts were used to fulfill the infrastructure development's financing, so that the burden on the state budget could be reduced. One that is used by the 
Government is to involve the private sector in infrastructure development. This means that even state-owned enterprises (SOE) can be involved in infrastructure development. This involvement is legalized through the Presidential Regulation Number 38 of 2015 concerning public private partnership in Infrastructure Development. This is intended to strengthen the PPP scheme in a juridical manner in the Indonesian legislation system, so that it becomes the operational driving force for the implementation of PPP in Indonesia and to increase institutional capacity and human resources that handle infrastructure. Of course, the ultimate goal is for PPP to provide maximum benefits for infrastructure development in Indonesia.

However, in practice, there are facts that raise questions in the implementation of PPP. Like, about the selection of the Implementing Business Entity (IBE) for infrastructure development projects. Ideally, the selection of IBE according to Article 12 paragraph (2) of Presidential Regulation No. 38 of 2015 is carried out through an auction mechanism or direct appointment. Clearly, there are only two methods to determine the IBE that will become the government's collaborative partner to build infrastructure. However, empirical reality shows that there are other methods to determine IBE as a collaborative partner of the Government to build infrastructure. That particular another method is assignment.

The method can be seen from the LRT infrastructure development project integrated in the Jakarta, Bogor, Depok and Bekasi regions, when the Government through Presidential Regulation No. 98 of 2015 concerning the Acceleration of the Implementation of LRT Integrated in the Region Jakarta, Bogor, Depok and Bekasi, as amended by Perpres No. 49 of 2017, assign the SOE, namely Ltd. Adhi Karya, To build the integrated LRT infrastructure. In addition, the assignment of Ltd. Kereta Api Indonesia to organize the infrastructure and facilities of the Soekarno-Hatta Airport railroad and the Jakarta-Bogor-Depok-TangerangBekasi ring line also occurred with the same method and was legalized through Presidential Regulation No. 83 of 2011. A similar method also occurred with Ltd. Jasa Marga is in the construction of toll roads, and Ltd. Housing Development, Wakita Karya, Wijaya Karya and Hutama Karya.

The problem is whether this method has the opportunity to be carried out by the Government? if it turns out yes, what conditions makes the government use the assignment method to choose the IBE. Then, what are the potential conflicts of interest in the assignment method? The potential for conflict of interest in the assignment method is important to question because based on the understanding of conflict of interest is "conflict between public responsibility and personal or group interests." In conflicts of interest, public officials have the potential to abuse their power to fulfill their own interests or groups, so that serving the public is not optimal. there will even be an urge to abuse power and authority to divert the use of the budget to personal or group interests, resulting in a mode of corruption such as procurement of goods and services fictitious, tax manipulation, or "parking money".

In addition to the challenges, what must be sought and found in this study are the opportunities caused by this assignment method in infrastructure development through the PPP mechanism. The results of the research on these problems, set forth in a system that consists of an introduction that contains an overview of the circumstances that trigger the emergence of a problem examined in this study. Second, is the method. This method describes the way in which this problem is solved, or at least obtained a finding that brings the researcher to the truth even though it is relative. Next is the result and discussion in which the results of the research have been described, and the elaboration of the doctrines or normative provisions that govern the facts and reality about PPP. The last is the conclusion and recommendation. In this section, described the conclusions of various findings and analyzes 
that have been carried out, after that, the researcher will describe the solution as a recommendation of the problems in this study.

\section{Methods}

The problem in this study was solved using normative approaches and concepts. Normative stressors and concepts are needed to solve problems regarding opportunities for assignment methods carried out by the Government to select the IBE in the implementation of a PPP's project, and regarding the circumstances that encourage the government to use the assignment method to select IBE, also regarding the potential conflicts of interest that are very likely to occur in this assignment method, and that is why referrals to legislation governing PPP and concepts, doctrines or teachings regarding conflicts of interest according to State Administrative Law are urgently needed

Through this approach, the normative legal research method that used is based on the secondary data. Secondary data used in this study which is in accordance with the normative approach to solve the problem regarding the opportunity of the assignment method carried out by the Government to select IBE in PPP's projects is the legislation governing the PPP. Of course the legislation comes from primary legal material. Meanwhile, the problem regarding the situation that prompted the government to use the assignment method and about conflicts of interest was resolved by a conceptual approach that originated from secondary legal materials, namely expert writings, whether through books or journal articles and even articles in print and electronic media. Legal material that is the source of data is obtained through the study of documents or literature which are then analyzed qualitatively. Of course, before being analyzed, the data is validated by using coding techniques, so that the data used is relevant to the problem and can be used to find out the truth of a problem.

\section{Results and Discussion}

\subsection{Infrastructure in Indonesia and its Evolution}

Equitable infrastructure in Indonesia which has 34 provinces is not an easy matter, it requires funds, adequate human resources, and careful planning so that development can be carried out effectively and on target. In the last four years, the structure of the Indonesian economy is still dominated by provincial groups in Java and Sumatra with a total GDP distribution of around $80 \%$, while the islands of Kalimantan, Sulawesi, Bali, Nusa Tenggara, Maluku and Papua are only around $19.6 \%$. difficulties and lack of access experienced by regions such as Papua, Maluku and the Sulawesi region are concrete evidence that infrastructure equality is needed. Finally, the Indonesian Government began to aggressively spread the issue of infrastructure development so that it can became the main focus in national development. The aim of intensifying infrastructure development in Indonesia is to improve the welfare of the Indonesian people by encouraging the pace of the economy through facilitating accessibility between one region and another.

Efforts to decompose justice through infrastructure development are very clearly seen, especially from the amount of budget prioritized by the government to develop infrastructure in various regions in Indonesia. Through a budget that is calculated to be around 400 trillion, inter-regional connectivity will begin to be built, such as toll roads, railroad additions and train services, airports and ports. Then supporting infrastructure for food security such as dams and 
reservoirs, as well as telecommunications such as palapa ring which makes Indonesia have a broadband or internet network at high speed. Based on the data, for 2016 to 2017, the JokowiJusuf Kalla Government has completed 30 (thirty) national strategic infrastructure projects, with a total project value of 94, 8 Trillion. Of the 30 projects, 20 of them are:

1. Gempol-Pandaan Toll Road, East Java with a length of $14 \mathrm{~km}$

2. Development of Soekarno Hatta Airport (Terminal 3), Banten

3. Kalibaru Port, DKI Jakarta

\subsection{Public Private Partnership as a Method of Improving Infrastructure Development}

Indonesia's requirement for infrastructure development is clear and certain. But to fulfill that, a large amount of budget is needed from the National budget, and that had become a major issue. Overcoming that, the Government is trying to involve the private sector in infrastructure development, known as Public Private Partnership (PPP). PPP is an idea that is considered capable of overcoming the problem of infrastructure development in Indonesia originating from the state budget financing.

In addition, the PPP's system is deemed capable of creating an investment climate of the Business Entity in the infrastructure development, and encouraging the principle of use-pay by users, or in certain cases considering the ability to pay from the user's side. The PPP's method or system is applied by adhering to the principles which if viewed philosophically, have a beneficial side for the state and society. And the beneficial are such partnerships, benefits, competing controls and risk management, effective and efficient. Thus, PPP's in the paradigm of infrastructure provider actors are considered as a method of increasing infrastructure development in Indonesia.

\subsection{Selection Method of Implementing Business Entities for Infrastructure}

Through PPP, Business Entities can cooperate with the Government in infrastructure development. this has been validated through Presidential Regulation Number 38 of 2015 concerning PPP in Infrastructure development. According to the Presidential Regulation, Business Entities that can cooperate with the Government to provide infrastructure are SOE, Regionally-Owned Enterprises, business entities in the form of Limited Liability Companies (Ltd), foreign legal entities or cooperatives. Whereas the IBE must be from the Limited Company established to carry out the PPP's project by the auction winner or business entity/consortium appointed directly. From this normative provision, it can be understood that those who become IBE for infrastructure projects are only companies in the form of limited liability companies, both from SOE, regional government-owned companies, foreign legal entities and cooperatives.

What needs to be underlined is that the Limited Liability Companies formed to carry out the PPP's project is by the auction winner's business entity or already through a direct appointment mechanism. Thus, the method used to select the IBE for infrastructure's project is the auction or direct appointment. This method has also been stated through Article 38 of Presidential Regulation No. 38 of 2015, that "the procurement of implementing business entities is carried out through an auction or direct appointment."

This provision was reaffirmed through the Regulation of the Government of the Republic of Indonesia Goods/Services Procurement Policy Number 29 of 2018 concerning Procedures for Procurement of Infrastructure Providing Business Entities through Government Cooperation with Business Entities, initiated by the Minister/Head of Institution/Regional Head. This regulation is the implementing regulation of Presidential Regulation No. 38 of 
2015. So the main point of discussion is the Regulation Number 29 of 2018 which states that the selection of IBE is conducted through an auction or direct appointment.

The selection of implementing business entities through the auction is conducted in 2 (two) ways, namely one-stage or two-stage auction. One-stage auction is carried out for PPP's projects if:

1. Can be clearly formulated regarding infrastructure requirements; and

2. There is no additional requirement or optimal dialogue to get the most useful offers with the best value for money.

The two-stage auction is carried out if the PPP project has formulated clearly and cannot be changed to the minimum requirements of infrastructure provision, and additional conditions and optimal dialogue are needed to obtain offers that have the best value for money. Circumstances that make certain conditions are differentiated again. For example the requirements for certain conditions that the Implementing Business Entity (IBE) had previously built and/or operated an infrastructure project that was being developed, then its performance was also assessed based on an independent audit, and the project was considered effective and efficient if it was built by the same IBE. Thus, the method of direct appointment cannot be arbitrarily carried out by the Government, without any clear reason or argument.

Wisely applied in the direct appointment based on land tenure. The government can make direct appointments to implementing business entity (IBE) that have controlled the land, if:

1. Land owned by IBE is the only land for infrastructure locations and cannot be moved; and

2. PPP projects have been declared technically, economically and financially feasible without Feasibility Support from the Government.

\subsection{Assignment: Opportunities and Challenges}

Presidential regulation Number 38 Year 2015 has determined that the selection of IBE is only through 2 (two) methods, namely auction and direct appointment. But empirically, the government conducted another method, namely by assignment. if referred to the provisions in Presidential Regulation No. 38 of 2015, it does not mention the assignment method. That is, the method is outside the 2 (two) methods mentioned above. Law number 19 of 2003 and Government Regulation number 45 of 2005, has the same statement that the Government provides special assignments for State-Owned Enterprises to carry out the function of public benefit and still paying attention to the main intention of the State-Owned Enterprise's activities, and must first obtain the approval of the Shareholders / Ministers. Things statement stated at article 66 paragraph (1) and paragraph (2) law 19 of 2003.

Further emphasized in the explanation of Article 66 paragraph (1) of Law 19 of 2003 that state-owned enterprises in urgent matters are given special assignments by the Government, and if the assignment according to the study is financially not feasible, the government must compensate all costs incurred this state-owned enterprise includes the expected margin. In addition, the assignment must also be known and approved by the general meeting of shareholders / Ministers.

In contrast to the auction method and the direct appointment of predetermined criteria for IBE as implementing PPP through implementing regulations of Presidential Regulation 38 of 2015, the assignment method to state-owned enterprises regulated in Law 19 of 2003 and Government Regulation No. 45 of 2005 provides provisions that:

1. Special assignments still pay attention to the intent and purpose and business activities of state-owned enterprises; 
2. The assignment plan is jointly reviewed between the relevant state-owned business entity, the Minister, the Minister of Finance, and the Taknis Minister who gave the assignment

3. The technical minister who gave the assignment as a coordinator;

4. If the assignment is financially unprofitable, the Government must provide compensation for all costs incurred by the state-owned enterprise, including the expected margin along the level of fairness in accordance with the assignment given

5. The assignment must be based on the approval of the Shareholders General Meeting for the Persero and the Minister for Public Corporation

6. State-owned business entities must expressly separate books regarding the assignment with bookkeeping in order to achieve the company's business objectives.

7. Director must provide a report to the general meeting of shareholders / Ministers, the Minister of Finance, and the Technical Minister who gave the assignment

This raises the understanding that the method of determining IBE is not only through auction and direct appointment, but also through assignments. Thus, the Government assignment method to BUMN based on Law 19 of 2003 and PP 45 of 2015 relating to the type of infrastructure specified in Article 5 paragraph (2) of Presidential Regulation 38 of 2015, has the opportunity to be done However, based on these provisions it can be understood that the Government can assign state-owned enterprises (SOE) to carry out activities related to PSO that are urgent, so that SOE does not only focus on seeking profits but also carry out public services, certainly accompanied by consideration financially from the SOE itself. As a platform for understanding the urgent of PSO, presidential Regulation Number 75 of 2014 concerning the Acceleration of Priority Infrastructure Provision can be used, so that assignments made by the Government to SOE for the provision of Infrastructure should pay attention to priority indications set by the Committee for Accelerating the Provision of Priority Infrastructure (CAPPI).

However, the determination of priority projects carried out by CAPPI is one of them based on proposals by ministers, heads of institutions, regional heads, SOE leaders, or leaders of regionally owned enterprises. This condition, which actually explains that open conflicts of interest occur in determining priority infrastructure projects and SOE to be assigned. In addition, excessive dependence on SOEs can "marginalize" the private companies and crowd out private investment in the domestic construction industry. As a result, competition between contractors has diminished and the amount of resources available for infrastructure development is limited.

On the other hand, if the assignment method is used in the PPP process without specifying the type of BUP, it will also have an impact on the business wheels of state enterprises, bearing in mind that BUP is not only SOE / ROE. Later this can be detrimental to the Indonesian economy. These conditions indicate that the assignment method has its own challenges, when it was chosen by the Government as a method for selecting BUP in implementing infrastructure development projects.

This suspicion further indicates the danger of the assignment method which seems to be used as the government's mainstay method in implementing PPP. If observed in the provisions of the Government assignment to SOE, the emphasis of the assignment acceptance decision is at the share voter general meeting of the SOE. potentially create a conflict of interest between the government which in this case is the minister in charge of carrying out infrastructure activities with SOE elements to be assigned, if the assignment is based on:

1. there are personal and/or business interests;

2. relationship with relatives and family; 
3. relationship with representatives of the parties involved;

4. relationship with the party who works and gets a salary from the parties involved;

5. relationship with the party providing recommendations to the parties involved; and/or

6. relations with other parties which are prohibited by the provisions of the legislation.

On the other hand SOE BUMN is domiciled as a provider of public services according to government policies that can work on infrastructure development projects, which results in accelerated development. In addition, another potential that can also occur due to this assignment method is the risk management periodically through monitoring the balance sheet capacity and BUMN liquidity conditions. With this situation, the weakening state finances caused by the weakening of SOE's balance sheet performance can be controlled. Thus, the assignment method in determining IBE for working on infrastructure projects saves the "black and white" side. Therefore, it is important to explore the potential of the opportunities provided, and not get caught up in the challenges, but look for solutions so that challenges can be faced.

\section{Conclusion and Recommendation}

The assignment method has the opportunity to be carried out by the Government in the implementation of PPP to determine IBE, but the assignment method is only intended for SOE and for the implementation of urgent infrastructure activities as stipulated in Article 66 of Law 19 of 2003. determining criteria for urgent conditions that determine the implementation of activities can be delegated to SOE through the assignment method. Finally, various infrastructure programs carried out through PPPs through assignments to SOEs are read as a form of accelerating the implementation of infrastructure development programs, is the risk management periodically through monitoring the balance sheet capacity and BUMN liquidity conditions.

With this situation, the weakening state finances caused by the weakening of SOE's balance sheet performance can be controlled. With this situation, the risk of state finances caused by the weakening of BUMN's balance sheet performance can be controlled. This situation is an opportunity for the use of the assignment method in establishing BUP for infrastructure development projects. While The absence of technical arrangements regarding the assignment of the implementation of infrastructure projects from the Government to the IBE has the potential to create a conflict of interest, both from the implementing elements or officials authorized to determine and accept assignments or conflicts of interest between IBE and the Government. so this becomes a challenge when the assignment method for establishing IBE.

Based on the conclusions that have been obtained, the recommendations generated from this research is the requirement to establish technical regulations regarding the assignment method to IBE, at least regulating the IBE criteria for each type of PPP activity and the criteria for PPP activities that determine IBE through assignment methods. This is important, to erode various challenges conflicts of interest.

\section{References}

[1] Bappenas. (2015). Kelembagaan untuk Akselerasi Infrastruktur, dalam Sustaining Partnership. Editorial. Bappenas: Infrastructure Reform Sector Development Program.

[2] Haryatmoko. Etika Publik dan Konflik Kepentingan. Home/Kompas. Accesed on 20 Juni 2019 dari

https://ekonomi.kompas.com/read/2011/06/07/03001349/etika.publik.dan.konflik.kepentingan. 
[3] Himawan, Adithya dan Dian Kusumo Hapsari. Ini Daftar 30 Proyek Infrastruktur Yang Telah Diselesaikan Jokowi. Accessed on 21 Juni 2019 dari https://www.suara.com/bisnis/2018/04/19/150203/ini-daftar-30-proyek-infrastruktur-yangtelah-diselesaikan-jokowi.

[4] Indonesia. Undang-Undang tentang Administrasi Pemerintahan. UU 30 Tahun 2014. Indonesia. Peraturan Presiden tentang Kerjasama Pemerintah dan Badan Usaha Dalam Penyediaan Infrastruktur. Peraturan Presiden Nomor 38 Tahun 2015.

[5] Indonesia. Peraturan Lembaga Kebijakan Pengadaan Barang/Jasa Pemerintah Republik Indonesia tentang Tata Cara Pengadaan Badan Usaha Pelaksana Penyediaan Infrastruktur Melalui Kerjasama Pemerintah Dengan Badan Usaha Atas Prakarsa Menteri/Kepala Lembaga/Kepala Daerah. Peraturan Lembaga Kebijakan Pengadaan Barang/Jasa Pemerintah Nomor 29 Tahun 2018.

[6] Kementerian Keuangan, Siaran Pers. Pengelolaan Risiko Atas Kinerja Keuangan BUMN dalam

Pembangunan Infrastruktur Nasional., Accessed on 10 august https://www.kemenkeu.go.id/media/9791/siaran-pers-pengelolaan-risiko-atas-kinerjakeuangan-bumn-dalam-pembangunan-infrastruktur-nasional.pdf..

[7] LPEM FEB Universitas Indonesia. (2018). Memaksimalkan Dampak Dari Inovasi Infrastruktur. Seri Analisis Makroekonomi. Indonesia Economic Outlook. Depok: LPEM FEB Universitas Indonesia.

[8] NN. Pertumbuhan ekonomi indonesia masih banyak dinikmati golongan menegah keatas. Accessed on 21 Juni 2019 dari https://nasional.kontan.co.id/news/pertumbuhan-ekonomiindonesia-masih-banyak-dinikmati-golongan-menengah-atas.

[9] NN. Kerjasama Pemerintah Dengan Badan Usaha (KPBU) Mengapa KPBU? Accessed on 21 Juni 2019 dari http://kpsrb.bappenas.go.id/data/filekpbu/tentang\%20KPBU\%20 (INDO).pdf.

[10] S, Andryanto. Indef: Penugasan Infrastruktur Pemerintah Berdampak Negatif Bagi BUMN. Accessed on 20 Juni 2019 dari https://www.google.com/search?safe=strict\&client=msandroid-

samsung\&ei $=$ sI8LXYzKD4fpvgTJ5boDQ\&q=penugasan + badan + usaha + untuk + membangun $+\mathrm{i}$ nfrastruktur\&oq-penugasan+badan+usaha+membangun+infrastruktur\&gs_l=mobile.

[11] Widyastuti, RR. Ariyani Yakti. Anggaran Infrastruktur 2019 Naik Jadi Rp 420,5 T, Ini Rinciannya. (Ed). Accessed on 20 Juni 2019 dari https://www.google.com/amp/s/bisnis.tempo.co/amp/1117/anggaran_infrastruktur_2019_naik_ jadi_Rp_420,5T_Ini_rinciannya_amp// 